\title{
Allochthonous vs, autochthonous energy resources for aquatic insects in cloud forest streams, Veracruz, Mexico
}

\section{Recursos energéticos, alóctonos o autóctonos, de los insectos acuáticos en arroyos de bosques nubosos, Veracruz, México}

\author{
Pavel García ${ }^{1-3}$, Rodolfo Novelo-Gutiérrez ${ }^{1}$, Gabriela Vázquez and Alonso Ramírez² \\ IInstituto de Ecología, A.C. Red de Biodiversidad y Sistemática Carretera Antigua a Coatepec 351, El Haya 91070 Xalapa, Veracruz, México \\ 2Department of Environmental Sciences, University of Puerto Rico, P0 Box 190341, San Juan, 00919. Puerto Rico \\ ${ }^{3}$ Escuela de Biología, segundo nivel Edificio T-10, Ciudad Universitaria, Zona 12, Guatemala, 01012. Guatemala \\ e-mail: pavelernest@gmail.com
}

Recibido: 19 de mayo de 2015.

Aceptado: 07 de mayo de 2016.

García P., R. Novelo-Gutiérrez, G. Vázquez and A. Ramírez. 2016. Allochthonous vs. autochthonous energy resources for aquatic insects in cloud forest streams, Veracruz, Mexico. Hidrobiológica 26 (3): 483-496.

\begin{abstract}
Background. Recent tropical studies question the assumption that forested headwater streams rely on allochthonous resources as their main energy source, suggesting that autochthonous resources are more important. Goals. Here, we characterized the energy base, as gut contents, of cloud forest streams with contrasting riparian vegetation cover in Veracruz, Mexico, during dry, rainy and "nortes" (e.g., less dry and cold) seasons. Methods. Two first-order streams were selected for the study - one flowing through forest and the other through pasture with sparse riparian vegetation. Gut content analyses showed aquatic insect diets composed of diatoms, green algae, fungi, plant tissue, and amorphous detritus. Results. The forest stream had taxa with gut contents composed of 31 to $99 \%$ allochthonous material, while the pasture stream reached a maximum of $82 \%$ during "nortes". Diatoms accounted for most of the autochthonous material in guts, especially in the pasture stream during the dry season. A significant proportion of ingested allochthonous material was fungi, mainly in the forest stream during the rainy season. Conclusions. Overall, our study supports the view that in forested tropical streams autochthonous material is an important food resource. However, allochthonous material was found to be an important food item, even in pasture streams with limited riparian cover.
\end{abstract}

Key words: Allochthonous and autochthonous material, cloud forest, food-webs, guts contents, Neotropical streams, trophic basis.

\section{RESUMEN}

Antecedentes. Estudios recientes en el área tropical han cuestionado si el material alóctono es la principal fuente de energía en arroyos ubicados en cuencas con cobertura boscosa conservada, sugiriendo que los recursos autóctonos son más importantes de lo esperado. Objetivos. Aquí nosotros caracterizamos la base energética, por medio de análisis de contenido estomacal, en arroyos de bosque mesófilo montano que contrastan en la cobertura de la vegetación ribereña en Veracruz, México, durante las épocas seca, de lluvias y nortes. Métodos. Se seleccionaron dos arroyos de primer orden para el estudio, uno que atraviesa un área de bosque conservado y otro que pasa a través de un área de pastizal con escasa vegetación ribereña. El análisis de contenido estomacal mostró que la dieta de los insectos acuáticos estaba compuesta por diatomeas, algas verdes, hongos, tejido vegetal y detritos amorfos. Resultados. En el arroyo del bosque Ios taxa tenían un contenido estomacal compuesto por material alóctono de un 31 a 99\%, mientras que en el arroyo del pastizal el material alóctono alcanzaba un máximo de $82 \%$ durante la época de nortes. Las diatomeas representaron la mayor cantidad de material autóctono, especialmente en el arroyo del pastizal durante la época seca. Los hongos fueron una alta proporción del material alóctono, principalmente en el arroyo del bosque durante la época lluviosa. Conclusiones. En general nuestro estudio da soporte a la propuesta de que el material autóctono es un recurso energético importante. Sin embargo, se encontró que el material alóctono es un recurso importante, incluso en el arroyo del pastizal.

Palabras clave: Arroyos neotropicales, bosque mesófilo de montaña, cadenas tróficas, contenido estomacal, material alóctono y autóctono. 


\section{INTRODUCTION}

The energy base of the ecosystem affects both stream food web structure and stream diversity, and changes in resource availability result in changes in the structure and diversity of aquatic food webs (RosiMarshall \& Wallace, 2002; Benstead et al., 2003; Benstead \& Pringle, 2004). In these webs, aquatic insects are an important link between allochthonous and autochthonous energy resources and higher trophic levels in streams. Aquatic insects consume allochthonous and autochthonous material suspended in the water column, biofilms that grow on stones, wood or litter deposited on streambeds, or fine particulate matter that accumulates on stream bottom (Cummins \& Klug, 1979; Cummins et al., 2005). For their part, insects represent an important food item in the diet of many other stream invertebrates, fishes, and riparian predators (Allan \& Castillo, 2007).

In temperate regions, low-order stream food webs are known to be based largely on allochthonous material (Rounik et al., 1982; Wallace et al., 1997; Hall et al., 2001; Rosi-Marshall \& Wallace, 2002; England \& Rosemond, 2004). Most evidence comes from headwater streams with large amounts of riparian vegetation receiving allochthonous material in the form of leaf litter and other terrestrial detritus, which are transported to streams by runoff or wind (Fisher \& Likens, 1973; Hynes, 1975; Minshall, 1978; Vannote et al., 1980). Aquatic insects, as a part of food webs, have different degrees of specialization and assimilation of food resources. Some rely almost entirely on allochthonous or autochthonous material, and so tend to be scarce, have less biomass, or are completely absent in streams where the material on which they specialize is in short supply or absent (Wallace et al., 1997; Rosi-Marshall \& Wallace, 2002).

According to studies describing the trophic structure of tropical streams in Brazil, Hong Kong, and Puerto Rico, unlike temperate streams, autochthonous material plays an important role in supporting the secondary production of aquatic insects (March \& Pringle, 2003; Mantel et al., 2004; Brito et al., 2006; Lau et al., 2009b; Dudgeon et al., 2010). Even in shaded streams with a high contribution of allochthonous material, autochthonous material comprised between 60 and $70 \%$ of the base for food-webs (March \& Pringle, 2003; Brito et al., 2006; Lau et al., 2009b). This difference in the energy base for secondary production has been attributed to several possible causes, all linked to the characteristics of leaf litter and its degradation, and relative to the availability of algae. It has been argued that vegetation in the tropics has a higher content of secondary compounds that can reduce their palatability (Ardón \& Pringle, 2008; Boyero et al., 2009). It may also be attributed to insect shredders, which are scarce in tropical streams (Li \& Dudgeon, 2008; Jacobsen et al., 2008), such that other processes may degrade plant litter, such as increased bacterial activity due to warmer water temperatures, or by other organisms such as fish and shrimp (Ramírez \& Pringle, 1998).

The trophic base of a stream is affected by seasonal variation of leaf-fall in autumn or snowmelt during spring in temperate zones, which changes the entry and availability of allochthonous material (Fisher \& Likens, 1973; Allan \& Castillo, 2007). In some parts of the tropics, there is stronger seasonal variation in rainfall and subsequent runoff, which transports leaf litter and debris from riparian areas to streambeds (Fisher \& Likens, 1973; Allan \& Castillo, 2007). Seasonal changes in rainfall also cause changes in stream flow, enhancing nutrient renewal, $\mathrm{CO}_{2}$, and $\mathrm{O}_{2}$, which benefit algal productivity and growth. However, heavy rains also cause increases in flow that might reduce the availability of allochthonous and autochthonous material (Allan \& Castillo, 2007). Studies that have evaluated the effect of rainfall seasonality on the food resources (Lau et al., 2009a; Molina et al., 2011) reported that, despite seasonal variation, autochthonous material is an important energy resource for aquatic insects in tropical streams.

In this study, we analyzed gut contents of aquatic insects from streams draining areas of Neotropical cloud forest in central Mexico, with contrasting amounts of riparian vegetation and during different seasons. The objectives were: 1) to characterize the trophic base for insect assemblages in two first-order streams draining cloud forest, but with contrasting amounts of riparian vegetation coverage; 2) to assess whether the presence of conserved riparian vegetation results in differences in the trophic base for aquatic insects; and 3) to determine whether seasonality modifies the trophic base for aquatic insect assemblages. The following hypotheses were proposed: a) as riparian vegetation can reduce light availability and limit primary productivity, aquatic insects in first-order streams with conserved riparian vegetation should have a different trophic base than those from streams where riparian vegetation has been reduced or removed, and b) as seasonality in tropical areas is mostly manifested as changes in flow and flow-related disturbance (e.g. floods), the trophic base for aquatic insects is expected to change among seasons.

Overall, our study supports the view that in forested tropical streams autochthonous material is an important food resource. However, allochthonous material was found to be an important food item, even in pasture streams with limited riparian cover.

\section{MATERIAL AND METHOD}

Study system. We conducted the study in the Reserva Natural La Cortadura, in the municipality of Coatepec, located in the central highlands of the state of Veracruz, Mexico (Fig. 1). The area is located on the eastern slope of Cofre de Perote Mountain between 1800 and 2000 masl, an area dominated by humic andosol soils of volcanic origin. The climate in this area is temperate humid with an average temperature of $18^{\circ} \mathrm{C}$ (minimum and maximum $10-14{ }^{\circ} \mathrm{C}$ to $20-23^{\circ} \mathrm{C}$ ) and an annual rainfall of $1,500 \mathrm{~mm}$ (Muñoz-Villers, 2008). Williams-Linera (2007) divided the year into three climatic seasons: a windy season from November to March characterized by the influence of polar air that generates fog, low temperatures, and light rain, known as "nortes"; a dry season from April to May characterized by high temperatures, low rainfall, and an increase in daylight hours and solar radiation; and a rainy season from June to October characterized by warm temperatures and abundant rainfall.

The vegetation cover of La Cortadura corresponds to Montane Cloud Forest (MCF), a tropical ecosystem characterized by high biodiversity (Rzedowski, 1978; 1996). Approximately $80 \%$ of the surface area corresponds to MCF and $20 \%$ to other land uses, such as pasture and crops (García-Franco et al., 2008). Dominant tree species present in the zone include Liquidambar styraciflua Linnaeus, 1753, Quercus xalapensis Bonpland, 1809, Q. leiophylla Alphonse de Candolle, 1864, Q. germane Schlechtendal \& Chamisso, 1830, Clethra mexicana Alphonse de Candolle, 1839, Turpinia occidentalis (Olof Swarf) George Don, 1832, Cinnamomum effusum (Meisner) Kostermans, 1961, Carpinus caroliniana Walter, 1788 and Oreopanax xalapensis (Kunth) Decaisne \& Planchon, 1854 (García-Franco et al., 2008). 
Our work focused on two first-order streams with contrasting levels of riparian vegetation (Fig. 1). The forest stream (19² $29^{\prime} 9^{\prime \prime} \mathrm{N}, 97^{\circ}$ 2' $29^{\prime \prime}$ W) had a high percentage of riparian cover, while the pasture

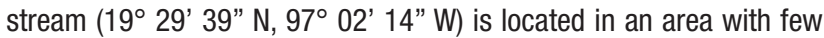
shrubs and trees. In each stream, a $200 \mathrm{~m}$ study reach was selected. Using aerial digital orthophoto E14B36C2 from the Instituto Nacional de Estadística y Geografía (INEGI), it was determined that the forest stream has a watershed with $78.2 \%$ of forest cover, while coverage for the pasture stream corresponded to $66.6 \%$ in forest and most of the pasture area located near the channel.

Measurements in situ. Stream discharge (D) was estimated at the most downstream point of each stream reach along a channel crosssection by $D=A v$, where $A$ is the area $\left(\mathrm{m}^{2}\right)$ and $v$ is the water velocity $\left(\mathrm{m} \mathrm{s}^{-1}\right)$ (Gore, 2007). Along a channel cross-section, we measured every 40 to $55 \mathrm{~cm}$ to have three measurements (edges and center) the depth and current velocity. Each record were measured with a ruler and a flow meter (FlowProbe 101-FP201), respectively. A multi-parameter probe (YSI Model 85 ) was used to measure temperature $\left({ }^{\circ} \mathrm{C}\right)$, conductivity ( $\mu \mathrm{S}$ $\mathrm{cm}^{-1}$ ) and dissolved oxygen ( $\left.\mathrm{mg} \mathrm{L}^{-1}\right)$, and a pH with a potentiometer (Barnant Model 20). Measurements were taken at the same location during the dry season (March 27 and April 1, 2011), the rainy season (August 14, 2011) and the "nortes" season (February 8 - 10, 2012).

Autochthonous and allochthonous materials. The availability of autochthonous material (autotrophic organisms such as benthic algae) was measured during each season as the concentration of chlorophyll a from nine stones (3-7 cm in diameter). Stones were collected randomly along the $200 \mathrm{~m}$ reach. Each stone was individually placed in $90 \%$ methanol and kept refrigerated in darkness for 24 hours to extract chlorophyll a. Chlorophyll a was measured by spectrophotometry and concentrations ( $\mathrm{mg} \mathrm{m}^{-2}$ ) were determined using the equations of Holden (Meeks, 1974). The availability of allochthonous material was also estimated along the study area as the amount of leaf litter accumulated per unit area. Nine Surber samples $(30 \times 30 \mathrm{~cm}$ frame) were randomly collected from each study reach. Samples were dried and burned at $550{ }^{\circ} \mathrm{C}$ for 1 hour to obtain the ash-free dry mass per unit area $\left(\mathrm{g} \mathrm{m}^{-2}\right)$ (Benfield, 2007).

Aquatic insects. Aquatic insects were collected from the edges and mid-channel sections of the streams, covering different microhabitats in pools and riffles along the chosen reach. A maximum of 10 individuals per taxon, or the maximum number possible, were collected at each sampling date. Samples were kept in Kahle's solution for 72 hours and then switched to $80 \%$ ethanol. Using Merritt et al. (2008), most individuals were identified to genus, with some exceptions that were left at the family or subfamily level, such as with the Muscidae and Chironomidae (Diptera). Each taxon was assigned to a functional feeding group (FFG) following Cummins et al. (2005) and Merritt et al. (2008): collector-gatherer, scraper, collector-filterer, shredder, piercer, and predator. For each taxon, at least one reference specimen was deposited in the entomological collection (IEXA) in the Instituto de Ecología, A.C.

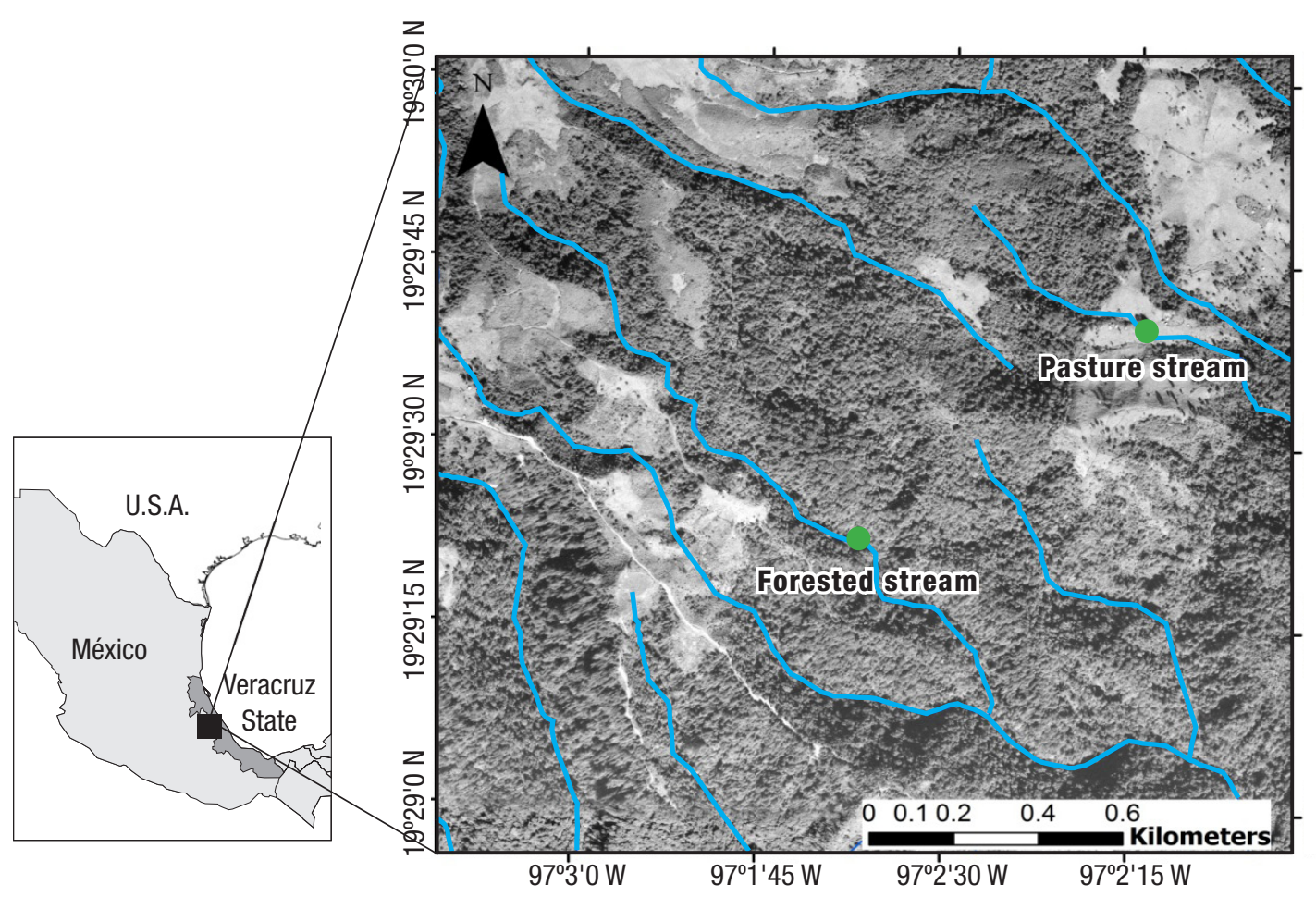

Figure 1. Location of La Cortadura and studied streams in forest and pasture land in the mountains of central Veracruz State, Mexico. (Map source: Mexico and Veracruz state contour: Comisión Nacional para el Conocimiento y Uso de la Biodiversidad (2002). Government policy. Scale 1:1,000,000. Image: digital orthophoto E14B36C2 of aerial photographs scale 1:40,000, November 2004, INEGI). 
Gut analysis. Gut content analysis was performed on all taxa that were not predators, as it was our goal to assess the trophic basis of primary consumers. Priority was given to taxa that actively search for food, such as those belonging to the collector-gatherers and scrapers. In addition, taxa for which more than four individuals were collected for at least one season in at least one of the streams were also analyzed.

Gut content analysis, involved the preparation of microscope slides with the gut contents of up to ten individuals by season and stream for each of the selected taxa following the methodology proposed by Cummins (1973). Agglomerations of gut contents were dispersed by vibration using an ultrasonic cleaner (NeyTech ULTRAsonik ${ }^{T M}$, Model 208H). Gut contents were concentrated on $0.45 \mu \mathrm{m}$ filters (Gelman Sciences, VWR P/N 64191), treated for 24 hours with immersion oil, and then sealed with Euparal. Slides were viewed at 400x magnification using a compound microscope. Forty-eight fields per slide were counted and the fields were located along five transects. To cover most of the gut content and avoid counting particles more than once, $2 \mathrm{~mm}$ were left between fields and $4 \mathrm{~mm}$ between transects. Gut contents were classified into six categories: diatoms, green algae, fungi, plant tissue, animal tissue, and amorphous detritus. Filamentous algae and diatoms were identified to genus according to Bourrelly (1966) and Kramer \& LangeBertalot (1991a;1991b; 1997; 1999).

Data Analysis: Basal energy resources. To compare the concentrations of chlorophyll $a$ and the amount of leaf litter between streams as potential responses to riparian vegetation cover and season, we used a nonparametric multivariate analysis of variance for permutations (perMANOVA) two-way in univariate way (Anderson, 2001). Euclidean distance was used for comparisons.

Taxa composition between streams. A hierarchical cluster analysis was used to evaluate the similarity of aquatic macroinvertebrate taxa composition between streams for each season. Because the analysis was qualitative, a weighted-average group algorithm and Sorensen's similarity index were used as measures of distance (Legendre \& Legendre, 1998).

Gut contents. We assessed whether the number and relative abundance of each of the six particle categories from gut contents of the different taxa varied due to riparian vegetation cover (forest, pasture) and season (dry, rainy, "nortes") using multivariate perMANOVA (Anderson, 2001). A two-way perMANOVA was used for taxa found during the same seasons in both streams, while for taxa collected from both streams during one season or one of the streams during two or three seasons, a one-way perMANOVA was used. Bray-Curtis distances were used for these analyses.

Allochthonous/autochthonous energy base. To determine what proportion of the trophic base was allochthonous or autochthonous, gut content categories were grouped according to their origin. Autochthonous material included green algae and diatoms, while allochthonous material included fungi and plant tissue (Graça, 2006). Particles classified as amorphous detritus or animal tissue were not included in the analysis as they can be either allochthonous or autochthonous in varying proportions (Rosi-Marshall \& Wallace, 2002; Li \& Dudgeon, 2008; Lau et al., 2009a).

Variations in the trophic base associated to riparian vegetation cover and season were also evaluated using perMANOVA. Two-way perMANOVAs were used for taxa found in the two streams during at least two seasons and one-way for taxa collected in the two streams during the same season or in one of the streams during two or three seasons. Bray-Curtis distances were used for these analyses.

For each perMANOVA, 999 permutations were performed. Using homogeneity analysis based on the dispersion distances and nonmetric multidimensional scaling, where significant differences were observed, they were between streams and/or seasons and not due to dispersion (Anderson, 2001; 2006; Anderson et al., 2008). All analyses were performed using the Vegan package, v2.0-3 for R v2.15.

\section{RESULTS}

Stream physicochemistry. Temperatures ranged between 11.2 and $18{ }^{\circ} \mathrm{C}$ in the two streams, with larger variation between seasons observed in the forest stream than in the pasture stream (Table 1). In both streams, dissolved oxygen was above $6 \mathrm{mg} \mathrm{L}^{-1}$, except for the forest stream during the dry season (Table 1). Water $\mathrm{pH}$ tended to be neutral (Table 1), except for the forest stream during the rainy and "nortes" seasons, which tended to be slightly acidic. The forest stream had lower conductivity than the pasture stream (Table 1). In both streams, flow increased during the rainy season compared to the dry and "nortes" seasons, with the highest values in the forest stream (Table 1). Stream width varied between 1 and $2.5 \mathrm{~m}$, with depths between 0.01 and $0.45 \mathrm{~m}$.

Table 1. Physicochemical parameters measured for two streams in La Cortadura, Coatepec, Veracruz, Mexico.

\begin{tabular}{|c|c|c|c|c|c|c|}
\hline & \multicolumn{3}{|c|}{ Forest } & \multicolumn{3}{|c|}{ Pasture } \\
\hline & Dry Season & Rainy Season & "Nortes" Season & Dry Season & Rainy Season & "Nortes" Season \\
\hline Temperature $\left({ }^{\circ} \mathrm{C}\right)$ & 18.00 & 13.50 & 11.2 & 17.10 & 15.20 & 14.1 \\
\hline Dissolved Oxygen $\left(\mathrm{mg} \mathrm{L}^{-1}\right)$ & 4.78 & 6.38 & 7.96 & 6.34 & 6.13 & 7.66 \\
\hline $\mathrm{pH}$ & 6.50 & 5.70 & 5.73 & 6.56 & 6.55 & 6.32 \\
\hline Conductivity $\left(\mu \mathrm{S} \mathrm{cm}^{-1}\right)$ & 26.20 & 12.30 & 17.5 & 42.22 & 41.76 & 40.8 \\
\hline Flow $\left(\mathrm{m}^{3} \mathrm{~s}^{-1}\right)$ & 0.012 & 0.18 & 0.05 & 0.021 & 0.14 & 0.13 \\
\hline Width (m) & 2.50 & 1.65 & 1.00 & 1.65 & 1.60 & 1.65 \\
\hline Min- Max Depth (m) & $0.070-0.10$ & $0.050-0.080$ & $0.01-0.06$ & $0.18-0.30$ & $0.10-0.14$ & $0.17-0.45$ \\
\hline
\end{tabular}


Availability of autochthonous and allochthonous material. Chlorophyll a levels were significantly higher $\left(\mathrm{F}_{1,48}=13.53, p<0.01\right)$ in the pasture stream $\left(17.61 \pm 2.39 \mathrm{mg} \mathrm{m}^{-2}\right)$ than in the forest stream $(7.72 \pm$ $2.10 \mathrm{mg} \mathrm{m}^{-2}$ ). We also found a significant effect of season on chlorophyll a levels $\left(F_{1,48}=9.86, p<0.01\right)$, with lower values during the "nortes" season $\left(4.40 \pm 1.06 \mathrm{mg} \mathrm{m}^{-2}\right)$ than during the dry $\left(18.28 \pm 3.02 \mathrm{mg} \mathrm{m}^{-2}\right)$ $(p<0.01)$ and rainy seasons $\left(15.31 \pm 3.31 \mathrm{mg} \mathrm{m}^{-2}\right)(p<0.01)$. Although there was no significant interaction between stream and season $\left(F_{148}\right.$ $=2.49, p=0.10$ ), forest stream chlorophyll a levels were lowest during the "nortes" season compared to "nortes" seasons at the pasture stream (Fig. 2).

Average leaf litter on the forest streambed $\left(94 \pm 13 \mathrm{~g} \mathrm{~m}^{-2}\right)$ was not significantly greater $\left(\mathrm{F}_{1,48}=3.39, p=0.06\right)$ than that recorded from the pasture stream $\left(62 \pm 12 \mathrm{~g} \mathrm{~m}^{-2}\right)$. However, there were significant differences in the amount of leaf litter among seasons $\left(\mathrm{F}_{1,48}=4.15, p\right.$ $=0.02)$, with the lowest quantity during the dry season $\left(43 \pm 15 \mathrm{~g} \mathrm{~m}^{-2}\right)$ than during the rainy $\left(96 \pm 18 \mathrm{~g} \mathrm{~m}^{-2}\right)(p=0.02)$ and "nortes" seasons $\left(96 \pm 14 \mathrm{~g} \mathrm{~m}^{-2}\right)(p=0.01)$. Between the rainy and "nortes" seasons there was no significant difference $(p=0.97)$ and no significant interaction between stream and season $\left(\mathrm{F}_{1.48}=0.33, p=0.73\right)$. There was an increase in the amount of leaf litter from the dry to the "nortes" season in the forest stream, while in the pasture stream there was more leaf litter during the rainy than in the "nortes" season; there was less during the dry season than in the other seasons (Fig. 3).

Aquatic insects. We collected 53 taxa distributed among 10 orders, 37 families, and 45 genera (Supplementary material 1). In the forest stream, 44 taxa were collected over three seasons, while in the pasture stream 45 taxa were collected. All taxa were classified into six FFGs, with the largest number of taxa classified as predators (21), followed by collector-gatherers (15), shredders (4), and piercer-herbivores (1).

Comparisons of compositional similarity of aquatic insect assemblages for both streams in a hierarchical cluster analysis (Fig. 4) showed that the composition among seasons in the pasture stream had the highest similarity (70\%). The composition of aquatic insects collected from

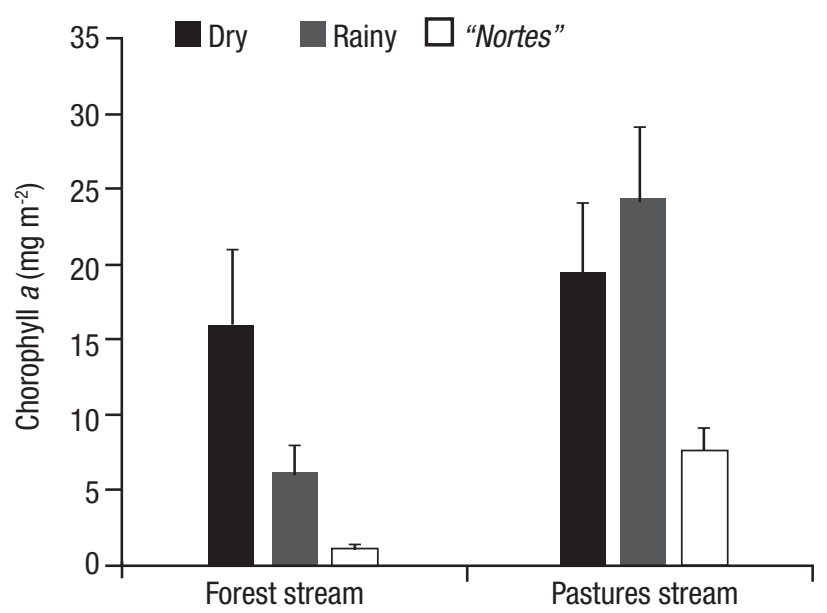

Figure 2. Average values (+ standard error) of the availability of autochthonous material measured as chlorophyll a from two streams in La Cortadura, Coatepec, Veracruz, Mexico, during the dry, rainy, and "nortes" seasons.

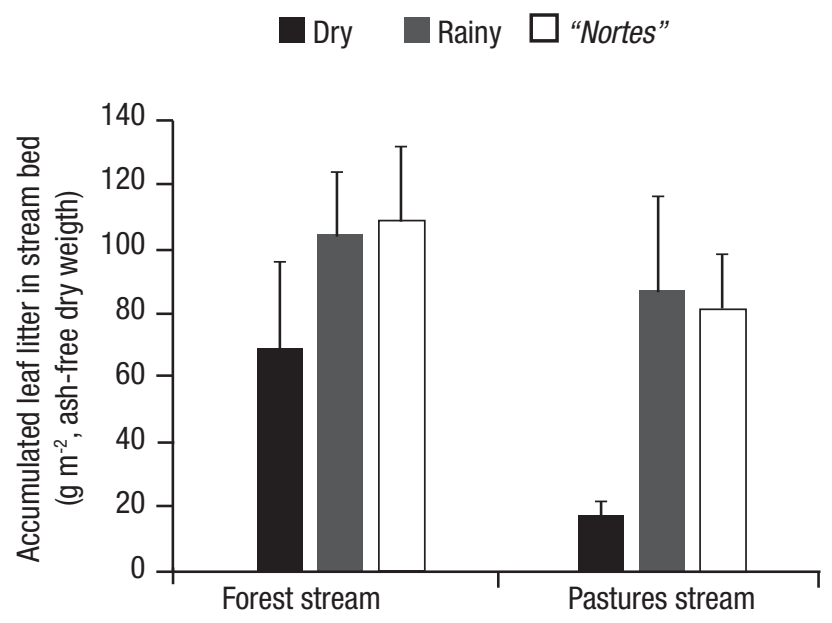

Figure 3. Average values (+ standard error) of available allochthonous material measured as leaf litter in the stream beds of La Cortadura, Coatepec, Veracruz, Mexico, during the dry, rainy, and "nortes" seasons.

the forest stream during the dry season had a greater similarity to that from the pasture stream (68\%) during the three seasons $(62 \%)$.

The gut contents of 324 individuals across 14 taxa distributed among 4 orders, 11 families, 2 subfamilies, and 12 genera were analyzed (Table 2), of which seven were collector-gatherers, four were scrapers, one was a collector-filterer, and two were shredders. Two of the scraper taxa, Epeorus Eaton, 1881 and Nixe Flowers, 1980 (Ephemeroptera: Heptageniidae), were grouped at the family level for analysis due to the low number of individuals collected.

Of the 14 taxa, three were collected during all three seasons in both streams: Epeorus + Nixe, Macrelmis Motschulsky, 1859 and Diplectrona J0 Westwood, 1840. Phylloicus F, Mueller, 1880 and Chironominae were collected during the dry and "nortes" seasons in both streams. Thraulodes Ulmer, 1920 and Orthocladinae were collected during dry season in both stream and during the rainy and "nortes" seasons only from the pasture stream. Psephenotarsis Arce-Pérez \& Novelo-Gutiérrez, 2001 was collected in both streams during the dry season. Lepidostoma Rambur, 1842 was collected during all three seasons, but only during the "nortes" season was it collected in both streams. Farrodes Peters, 1971 and Helicopsyche von Siebold, 1856 were collected in dry and "nortes" seasons, the first in the forest stream and the last one in pasture stream (Table 2).

Diet composition. Gut content analysis revealed that amorphous detritus was the most abundant particle type in all individuals collected from both streams (Figs. 5a-d, f, Supplementary material 2-4), except in those collected from the pasture stream during the rainy season (Fig. $5 e)$. In most larvae analyzed, the second and third most abundant food categories were diatoms and fungi. Among the diatoms found in the gut contents, 15 genera were identified (Table 3). Green algae, Closterium, Nitzsch ex Ralfs, Rivularia C. Agardh ex Bornet \& Flahault and Ulothrix Kützing, were observed in the gut contents of several taxa, but only in Lepidostoma and Phylloicus from the forest stream, they reached 2 and $3.5 \%$ of the gut contents, respectively. Animal tissue found was above $1 \%$ only in Diplectrona, representing between 1.2 and $2.8 \%$. 
Table 2. Aquatic insects from two streams in La Cortadura, Coatepec, Veracruz, Mexico, for which stomach contents were analyzed; functional feeding group (FFG) for each taxon (Cummins et al., 2005; Merritt et al., 2008).

\begin{tabular}{|c|c|c|c|c|c|c|c|}
\hline \multirow{2}{*}{ Taxon } & \multirow[b]{2}{*}{ FFG } & \multicolumn{3}{|c|}{ Forest } & \multicolumn{3}{|c|}{ Pasture } \\
\hline & & Dry Season & Rainy Season & "Nortes" Season & Dry Season & Rainy Season & "Nortes" Season \\
\hline \multicolumn{8}{|l|}{ Ephemeroptera } \\
\hline \multicolumn{8}{|l|}{ Baetidae } \\
\hline Fallceon & $\mathrm{CG}$ & 7 & 8 & - & 10 & 10 & 10 \\
\hline \multicolumn{8}{|l|}{ Heptageniidae } \\
\hline Epeorus & $\mathrm{Sc}$ & 2 & 2 & - & 1 & 7 & 3 \\
\hline Nixe & $\mathrm{Sc}$ & 7 & 1 & 4 & 5 & - & 2 \\
\hline \multicolumn{8}{|l|}{ Leptophlebiidae } \\
\hline Farrodes & $\mathrm{CG}$ & 6 & - & 7 & - & - & - \\
\hline Thraulodes & $\mathrm{CG}$ & 5 & - & - & 5 & 10 & 3 \\
\hline \multicolumn{8}{|l|}{ Leptohyphidae } \\
\hline Tricorythodes & CG & 2 & - & - & - & - & 10 \\
\hline \multicolumn{8}{|l|}{ Coleoptera } \\
\hline \multicolumn{8}{|l|}{ Elmidae } \\
\hline Macrelmis & CG & 10 & 4 & 9 & 8 & 7 & 9 \\
\hline \multicolumn{8}{|l|}{ Psephenidae } \\
\hline Psephenotarsis $^{T}$ & Sc & 6 & - & - & 5 & - & - \\
\hline \multicolumn{8}{|l|}{ Trichoptera } \\
\hline \multicolumn{8}{|l|}{ Calamoceratidae } \\
\hline Phylloicus & Sh & 4 & - & 5 & 2 & - & 10 \\
\hline \multicolumn{8}{|l|}{ Helicopsychidae } \\
\hline Helicopsyche & $\mathrm{Sc}$ & - & - & - & 10 & - & 3 \\
\hline \multicolumn{8}{|l|}{ Hydropsychidae } \\
\hline Diplectrona & $\mathrm{CF}$ & 5 & 5 & 5 & 5 & 5 & 3 \\
\hline \multicolumn{8}{|l|}{ Lepidostomatidae } \\
\hline Lepidostoma & Sh & - & 1 & 5 & 4 & - & 9 \\
\hline \multicolumn{8}{|l|}{ Diptera } \\
\hline \multicolumn{8}{|l|}{ Chironomidae } \\
\hline Chironominae & CG & 9 & - & 7 & 10 & - & 10 \\
\hline Orthocladinae & CG & 5 & - & - & 6 & 5 & 10 \\
\hline Total & & 66 & 21 & 42 & 71 & 44 & 82 \\
\hline
\end{tabular}

', For the area, two genera have been reported for the family Psephenidae: Psephenops and Psephenotarsis (pers. comm. R. Arce Pérez, Instituto de Ecología, A.C., Xalapa, Veracruz, México). $C G=$ Collector-gatherers. $C F=$ Collector-filterers. Sc $=$ Scrapers. Sh $=$ Shredders. $P=$ Predators

In most taxa, gut content composition varied significantly between streams and among seasons (Tables 4, 5). The difference in diet composition among taxa between the forest and pasture stream among seasons corresponded to changes in the percentage of amorphous detritus, with the lowest percentages in the pasture stream during the rainy season (Fig. 5e). In Fallceon Waltz and McCafferty, 1987, Heptageniidae, Chironominae, and Orthocladinae, there was a lower percentage of amorphous detritus in the gut contents of larvae from the pasture stream compared to the forest stream, and the least amount of amorphous detritus coincided with increased consumption of diatoms (Fig. 5). In Fallceon, the consumption of diatoms increased $76 \%$ during the rainy season in the pasture stream, while in the Orthocladinae and Chironominae the lowest proportion of diatoms in the gut contents was during the "nortes" season (Fig. 5f).
The diet of Psephenotarsis from the forest stream was different from those in the pasture stream (Table 5). There was a lower proportion of amorphous detritus and an increased consumption of diatoms by larvae in the forest stream than those from the pasture stream (Figs. $5 a, d)$.

In Phylloicus, the proportions of particles in gut contents were significantly different between streams and among seasons (Table 4). Plant tissue and fungi were the most abundant particles after amorphous detritus, and were more abundant in the gut contents of forest stream Phylloicus than those from the pasture stream. In addition, the proportion of plant tissue was higher during the "nortes" season (Figs. $5 a, c, d, f)$. 
Table 3. Diatom genera found in the stomach contents of aquatic insects from streams in La Cortadura, Coatepec, Veracruz, Mexico. Data are presence (1) and absence (0) for each of the two streams examined.

\begin{tabular}{lcc}
\hline Diatom Genera & Forest & Pasture \\
\hline Achnanthes Bory & 1 & 1 \\
Achnanthidium Kützing & 1 & 1 \\
Aulacoseira Thwaites & 1 & 1 \\
Cocconeis Ehrenberg & 1 & 1 \\
Cymbella C. Agardh & 1 & 1 \\
Fragilaria Lyngbye & 1 & 1 \\
Frustulia Rabenhorst & 1 & 1 \\
Gomphonema Ehrenberg & 1 & 1 \\
Melosira C. Agardh & 1 & 1 \\
Navicula Bory & 1 & 1 \\
Nitzschia Hassall & 0 & 1 \\
Pinnularia Ehrenberg & 1 & 1 \\
Rhoicosphenia Grunow & 1 & 1 \\
Eunotia Ehrenberg & 0 & 1 \\
Rhopalodia 0. Müller & 0 & 1 \\
\hline
\end{tabular}

Diplectrona and Macrelmis had a diet composition that varied significantly between streams and among seasons (Fig. 5, Table 4). In the forest stream during the dry season, after amorphous detritus, diatoms (4-10\%) were the most abundant particles (Fig. 5a). During the rainy season, fungi $(3.5-17 \%)$ and plant tissue $(3.5-6.2 \%)$ were the most abundant particles in the gut contents after amorphous detritus (Fig. 5b). During the "nortes" season, plant tissue (5.03 - 6.12\%) was the most abundant, after amorphous detritus (Fig. $5 \mathrm{c}$ ). In the pasture stream during the dry season, diatoms accounted for a greater percentage of gut contents in insects from the forest stream (Fig. 5d). During the rainy season, diatoms constituted 42 and $70 \%$ of the diets for Diplectrona and Macrelmis, respectively (Fig. 5e). During the "nortes" season the quantity of diatoms in gut contents declined, coinciding with the increase in the proportion of amorphous detritus and plant tissue in the gut contents (Fig. 5f).

In Thraulodes, during the dry season, diatoms (11.5 - 14.5\%) were the second most abundant particle category after amorphous detritus in the insect gut contents from both streams, followed by fungi (1.1 $3.2 \%)$ and plant tissue $(0.3-2.3 \%)$. Although the genus was not found during all seasons in the forest stream, we found that the diet of individuals collected from the pasture stream varied significantly $(p<0.01)$ among seasons. During the rainy season, diatoms comprised $46.9 \%$ and fungi $1 \%$, with the remainder being amorphous detritus (Fig. 5e). During the "nortes" season, diatoms comprised $8.97 \%$, fungi $7.36 \%$, and plant tissue $1.35 \%$ of gut contents.
In Lepidostoma from the forest stream, after amorphous detritus, the most abundant category was plant and fungal tissue (Figs. 5b, c), while in the pasture stream, diatoms were the next most abundant category (Figs. $5 \mathrm{~d}$, f). There was a greater proportion of diatoms in the insect gut contents from the pasture stream during the "nortes" season compared to the dry season.

Many individuals of Helicopsyche collected during the dry season were pupae. Larval gut contents were mainly composed of amorphous detritus and diatoms, with some individuals having consumed fungi, especially during the "nortes" season (Figs. $5 d$, f).

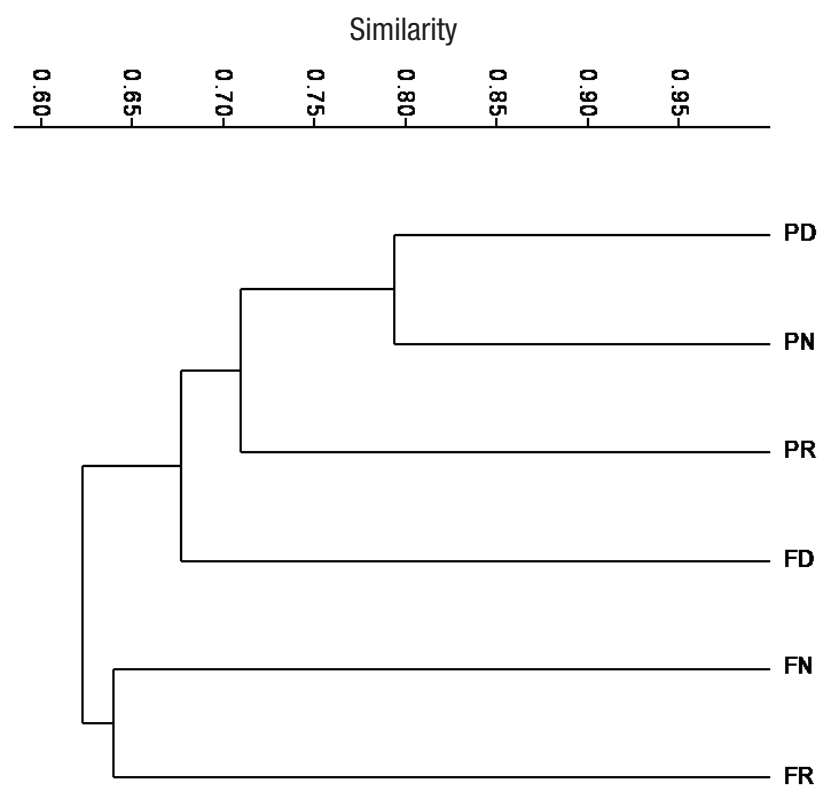

Figure 4. Hierarchical cluster analysis (average matched group algorithm and Sorensen similarity index) of aquatic insects richness in forest and pasture streams during the dry and rainy seasons in La Cortadura, Coatepec, Veracruz, Mexico; pasture stream during the dry season (PD), pasture stream during the rainy season (PR), pasture stream during the "nortes"season (PN), forest stream during the dry season (FD), forest stream during the rainy season (FR), and forest stream during the "nortes" season (FN).

Energy base of the food web. In the forest stream, allochthonous material comprised between 44 and $98.8 \%$ of the energy base for the aquatic insects examined (Figs. 6a-c), except for Psephenotarsis and Thraulodes during the dry season (Fig. 6a) and Heptageniidae during the rainy season (Fig. $6 \mathrm{~b}$ ), which had less than $40 \%$ of allochthonous material. In the pasture stream, the trend was toward a lower proportion of allochthonous material in the gut contents that ranged between $4.57-82.91 \%$ of the total (Figs. $6 \mathrm{~d}, \mathrm{e}, \mathrm{f}$ ).

The proportion of allochthonous material in the energy base was significantly lower $(p<0.05)$ during the rainy season compared to the dry and "nortes" seasons for most taxa from the two streams (Tables 4, 5) (Figs. 6a-f), especially for individuals collected from the pasture stream (Fig. 6e). For Thraulodes, Phylloicus, Helicopsyche, Chironominae, and Orthocladinae the proportion of allochthonous material in the diet was significantly higher $(p<0.05)$ during the "nortes" season. 

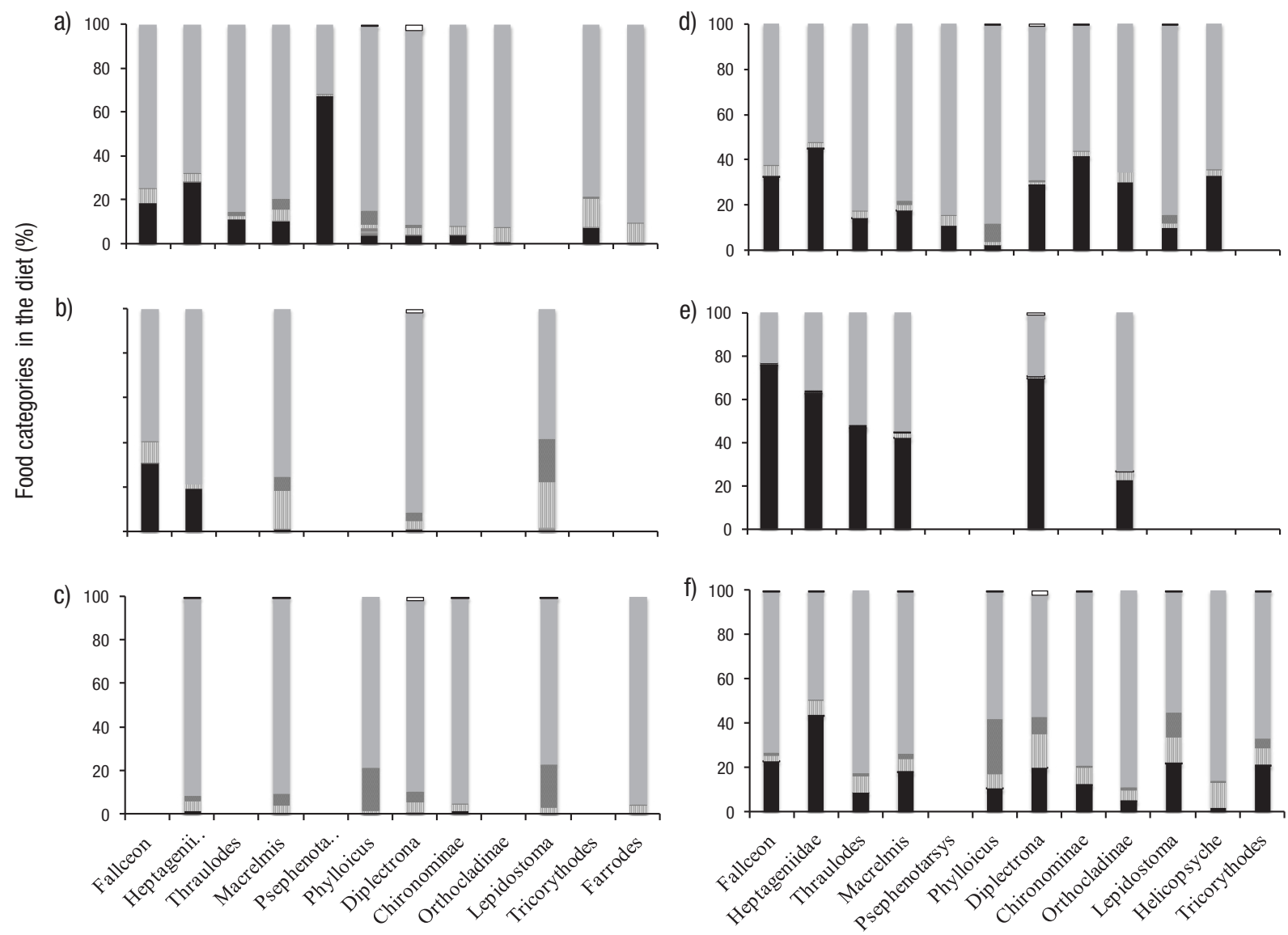

घiatoms $\quad$ Green Algae $\quad \square$ Fungi $\quad$ m Plant tissue $\quad \square$ Amorphous detritus $\quad \square$ Animal tissue

Figures 5a-f. Average diet composition from stomach content analyses of aquatic insects from streams in La Cortadura, Coatepec, Veracruz, Mexico: a) Diet of the taxa examined from the forest stream during the dry season; b) From the rainy season; c) From the "nortes" season; d) Diet of the taxa examined from the pasture stream during the dry season; e) During the rainy season; and f) During the "nortes" season. Gut contents were classified into six categories: diatoms, green algae, fungi, plant tissue, amorphous detritus, and animal tissue.

Of the six taxa (Table 4) for which gut contents were analyzed for at least two seasons in both streams, only for Macrelmis, Diplectrona, and Chironominae had significant interaction between stream and season. Diplectrona and Macrelmis presented different trends in each of the streams for the rainy season. In the forest stream, the food base was predominantly allochthonous (> $80 \%)$ (Fig. 6b), while in the pasture stream allochthonous material comprised less than $20 \%$ (Fig. 6e). For the Chironomidae, trends differed by stream for the dry season (Figs. $6 \mathrm{a}, \mathrm{c})$. In the forest stream, the amount of allochthonous material in the gut contents did not differ from that consumed during the "nortes" season $(p=0.07)$, although in the pasture stream the proportion of allochthonous material was lower $(p<0.01)$.

\section{DISCUSSION}

Previous work describing the food structure in tropical streams of Puerto Rico, Brazil, and Hong Kong (March \& Pringle, 2003; Mantel et al., 2004; Brito et al., 2006; Lau et al., 2009b; Dudgeon et al., 2010) has shown that autochthonous material plays a major role in the secondary production of aquatic macroinvertebrates in watersheds with dense riparian cover compared to temperate streams. However, the energy base for the MCF forest streams in this study comes from allochthonous material. The difference between this study and previous studies is likely due to the latter being conducted in third and fourth order streams in lowlands (March \& Pringle, 2003; Mantel et al., 2004; Brito et al., 2006; Lau et al., 2009b; Dudgeon et al., 2010) and to the large variation among tropical streams.

Availability of autochthonous and allochthonous material. According to Vannote et al. (1980), small streams with conserved riparian systems have a low availability of autochthonous material because incoming light is limited, thus limiting biomass and algal growth (Hill, 1996). This hypothesis is supported by the results obtained in this study, in which the forest stream had a lower availability of autochthonous material compared to the pasture stream, and by our previous work in the same area (Vázquez et al., 2011). Results are also consistent with other research in tropical streams (Larned \& Santos, 2000), where riparian vegetation creates a closed canopy that reduces light penetration, yielding lower primary productivity than in streams where less riparian vegetation allows more light to enter. 
Table 4. Two-way nonparametric multivariate/univariate analysis of variance (PERMANOVA) to evaluate the effect of stream (forest - pasture) and season (dry-D, rainy- $\mathrm{R}$, nortes-N) on the composition (number and relative abundance of components) of gut contents and the percentage of allochthonous material in some of the aquatic insects from streams in La Cortadura, Coatepec, Veracruz, Mexico.

\begin{tabular}{|c|c|c|c|c|c|c|c|c|c|}
\hline \multirow[t]{2}{*}{ Taxon } & \multirow[t]{2}{*}{ Source of Variation } & \multirow[t]{2}{*}{ DF 1} & \multirow[t]{2}{*}{ DF 2} & \multicolumn{2}{|c|}{ Gut contents } & \multirow[t]{2}{*}{ Seasons $p<0.05$} & \multicolumn{2}{|c|}{ Allochthonous Material } & \multirow[t]{2}{*}{ Seasons $p<0.05$} \\
\hline & & & & $\mathrm{F}$ & $p^{*}$ & & $\mathrm{~F}$ & $p^{\star *}$ & \\
\hline \multirow[t]{3}{*}{ Fallceon } & Stream & 1 & 31 & 13.49 & 0.002 & & 6.36 & 0.001 & \\
\hline & Season (D, R) & 1 & 31 & 14.48 & 0.001 & & 6.02 & 0.002 & \\
\hline & Interaction & 1 & 31 & 3.78 & 0.072 & & 1.53 & 0.18 & \\
\hline \multirow[t]{3}{*}{ Heptageniidae } & Stream & 1 & 28 & 16.21 & 0.001 & & 3.34 & 0.028 & \\
\hline & Season $(D, R, N)$ & 2 & 28 & 2.07 & 0.139 & & 5.09 & 0.003 & $\mathrm{R}$ \\
\hline & Interaction & 2 & 28 & 1.53 & 0.222 & & 1.04 & 0.403 & \\
\hline \multirow[t]{3}{*}{ Macrelmis } & Stream & 1 & 41 & 25.67 & 0.001 & & 9.69 & 0.001 & \\
\hline & Season $(D, R, N)$ & 2 & 41 & 6.51 & 0.001 & $\mathrm{R}$ & 7.47 & 0.002 & $\mathrm{R}$ \\
\hline & Interaction & 2 & 41 & 5.33 & 0.001 & & 7.57 & 0.001 & \\
\hline \multirow[t]{3}{*}{ Diplectrona } & Stream & 1 & 22 & 131.16 & 0.001 & & 81.09 & 0.001 & \\
\hline & Season $(D, R, N)$ & 2 & 22 & 15.91 & 0.001 & $\mathrm{D}, \mathrm{R}, \mathrm{N}$ & 17.22 & 0.001 & $\mathrm{D}, \mathrm{R}, \mathrm{N}$ \\
\hline & Interaction & 2 & 22 & 418.32 & 0.001 & & 16.35 & 0.001 & \\
\hline \multirow[t]{3}{*}{ Phylloicus } & Stream & 1 & 17 & 8.05 & 0.004 & & 10.56 & 0.005 & \\
\hline & Season $(D, N)$ & 1 & 17 & 5.55 & 0.015 & & 4.40 & 0.039 & \\
\hline & Interaction & 1 & 17 & 1.72 & 0.192 & & 2.05 & 0.15 & \\
\hline \multirow[t]{3}{*}{ Chironominae } & Stream & 1 & 32 & 60.10 & 0.001 & & 20.88 & 0.001 & \\
\hline & Season $(D, N)$ & 1 & 32 & 29.02 & 0.001 & & 15.85 & 0.001 & \\
\hline & Interaction & 1 & 32 & 16.17 & 0.001 & & 9.85 & 0.001 & \\
\hline
\end{tabular}

*Two-tailed analysis, $p(\alpha)<0.025 .{ }^{* *}$ One-tailed analysis, $p(\alpha)<0.05$. Season: D=Dry. R=Rainy. $\mathrm{N}=$ "Nortes".

Seasonal climate variation also affects the availability of autochthonous material. Our results suggest that increases in stream flow during the rainy season did not affect the availability of autochthonous material compared to the dry season, but it was less available during the "nortes" season. Flow during the rainy season probably did not increase enough to adversely affect the production and accumulation of autochthonous material. Although nutrient concentrations were not measured, algal growth could be enhanced by the increase in nutrient availability related to disruptions from increased flow (Grimm \& Fisher, 1989; Biggs, 1996; Allan \& Castillo, 2007). The decrease in autochthonous material during the "nortes" season was likely caused by the increased cloud cover and haze, which are common during this season, reducing the input of solar radiation (Williams-Linera, 2007). This tendency in the availability of autochthonous material coincides with previously observed trends in regional streams (Vázquez et al., 2011).
Headwater streams in forested watersheds receive large amounts of allochthonous material, mainly in the form of leaf-litter (Hynes, 1975; Webster et al., 1999). In spite of their contrasting amounts of riparian cover, the availability of allochthonous material in the two studied streams was similar. This lack of differences suggests the presence of additional sources of allochthonous detritus independent from riparian vegetation, highlighting the importance of vegetation found throughout the watershed and far from stream channels (Hynes, 1975). The pasture stream has $\sim 70 \%$ of catchment area cover with forest, mostly located far from the study stream reach, but still a likely source of allochthonous material in the streambed.

Similar to autochthonous material, allochthonous material availability could be affected by seasonal changes in climate. During the rainy and "nortes" seasons, the amount of leaf litter increased, potentially due to different processes. During the rainy season, the increased 
availability of allochthonous material is very likely the result of lateral transport via runoff (Fisher \& Likens, 1973). The observed increase during the "nortes" season occurs because it is the season of greatest leaf-fall for plants in the region, a pattern that is correlated with lowest temperatures during the year (Williams-Linera, 2007).

Aquatic insect diet. Most aquatic macroinvertebrates are expected to be generalists regardless of the feeding strategies used to capture their food (Cummins, 1973; Merritt et al., 2008). Our results support this observation as diet composition for all insect taxa involved at least five of the six gut content categories used in the study regardless of the FFG to which they belonged. Further, insect taxa assigned to different FFGs had the same pattern of variation in diet between streams and among seasons (e.g. Fallceon and Thraulodes or Heptageniidae and Psephenotarsis). Our results support the idea that it is not possible to assign taxa to FFGs based on gut content analysis (Palmer et al., 1993), because such a categorization is based primarily on the method of obtaining food and not on gut contents (Cummins \& Klug, 1979; Cummins et al., 2005; Merritt et al., 2008). Therefore, in this study, dietary analysis and origin of the trophic basis were conducted per taxon and not by FFGs.

The primary changes in diet composition among aquatic insect taxa between the two streams, and among seasons, corresponded to the proportion of amorphous detritus in the guts, the most abundant component also found in other studies (Palmer et al., 1993; Rosi-Marshall \& Wallace, 2002; Tomanova et al., 2006). In all cases where there was a lower proportion of amorphous detritus, there was an increase in the proportion of diatoms, fungi, and animal tissue. Although the examined aquatic insect taxa are generalists, there is some selection for items such as diatoms, algae, and animal parts over amorphous detritus, since the latter might have lower nutritional value depending on its origin (Cummins \& Klug, 1979; Rosi-Marshall \& Wallace, 2002).
In support of our prediction, the proportion of algae, particularly diatoms, in the gut contents was related to their availability in the environment. The proportion of diatoms was lower in taxa collected from the forest stream than from the pasture stream, coinciding with a lower availability of autochthonous material and supporting previous studies (Rosi-Marshall \& Wallace, 2002). In addition, the proportion of diatoms in the gut contents of more than $50 \%$ of the taxa was lower during the "nortes" season when light availability was reduced. It is noteworthy that although the availability of autochthonous material did not increase during the rainy season, the proportion of diatoms in gut contents tended to be higher than during the dry season in taxa collected from the pasture stream. One possible explanation is that, while the availability of autochthonous material in the stream did not change with the season, there was less competition during the rainy season for their consumption due to a lower abundance of aquatic insects (McNeely et al., 2007). Although our sampling did not allow for an analysis of abundance, the number of individuals is expected to be lower during the rainy season because increasing streamflow during this season can wash many individuals downstream (Leung \& Dudgeon, 2011). In addition, the abundance of aquatic insects can be lower during the rainy season due to the life-cycle, as is the case for Helicopsyche that were found mostly as pupae during the dry season, and none were collected during the rainy season.

Plant tissue and associate fungi were not abundant in the gut contents of all taxa, probably because the presence of cellulose and lignin makes plant tissue difficult to digest (Cummins \& Klug, 1979; Graça, 2006). However, the proportion of plant and fungal tissue in the gut contents was higher when the availability of benthic algae was lower, which occurs during the rainy and "nortes" seasons, especially in the forest stream. This could be simply a change in resource availability or

Table 5. One-way nonparametric multivariate/univariate analyses of variance (PERMANOVA) to evaluate the effect of stream (forest-F, pasture-P) or season (dry-D, rainy-R and nortes- $\mathrm{N}$ ) on the composition (number and relative abundance of the components) of the gut contents and the percentage of allochthonous material in some of the aquatic insects from two streams in La Cortadura, Coatepec, Veracruz, Mexico.

\begin{tabular}{|c|c|c|c|c|c|c|c|c|c|c|}
\hline \multirow[t]{2}{*}{ Taxon } & \multirow[t]{2}{*}{ Stream } & \multirow[t]{2}{*}{ Sources of Variation } & \multirow[t]{2}{*}{ DF 1} & \multirow[t]{2}{*}{ DF 2} & \multicolumn{2}{|c|}{ Stomach Contents } & \multicolumn{3}{|c|}{ Seasons $p<0.05$ Allochthonous Material } & \multirow[t]{2}{*}{ Seasons $p<0.05$} \\
\hline & & & & & $\mathrm{F}$ & $p^{*}$ & & $\mathrm{~F}$ & $p^{\star \star}$ & \\
\hline Fallceon & $P$ & Season $(D, R, N)$ & 2 & 27 & 24.97 & 0.001 & $R$ & 7.22 & 0.001 & $\mathrm{R}$ \\
\hline Farrodes & $P$ & Season (D, N) & 1 & 11 & 4.06 & 0.052 & - & 0.43 & 0.55 & - \\
\hline \multirow[t]{2}{*}{ Thraulodes } & $F, P$ & Stream & 1 & 8 & 0.61 & 0.5 & - & 0.63 & 0.56 & - \\
\hline & $P$ & Season $(D, R, N)$ & 2 & 15 & 17.02 & 0.001 & $\mathrm{R}$ & 4.74 & 0.006 & N \\
\hline Psephenotarsis & $F, P$ & Stream & 1 & 9 & 89.37 & 0.004 & - & 4.80 & 0.01 & - \\
\hline \multirow[t]{2}{*}{ Lepidostoma } & $F, P$ & Stream & 1 & 12 & 8.98 & 0.003 & - & 4.94 & 0.018 & - \\
\hline & $P$ & Season (D, N) & 1 & 11 & 5.10 & 0.015 & - & 0.79 & 0.51 & - \\
\hline Helicopsyche & $P$ & Season (D, N) & 1 & 11 & 4.36 & 0.046 & - & 3.07 & 0.036 & - \\
\hline \multirow[t]{2}{*}{ Orthocladinae } & $F, P$ & Stream & 1 & 9 & 34.2 & 0.005 & - & 17.35 & 0.004 & - \\
\hline & $P$ & Season $(D, R, N)$ & 2 & 18 & 11.48 & 0.002 & $\mathrm{~N}$ & 6.06 & 0.007 & $\mathrm{~N}$ \\
\hline
\end{tabular}

*Two-tailed analyses, $p(\alpha)<0.025 .{ }^{* *}$ One-tailed analyses, $p(\alpha)<0.05$ (- = Valores no registrados.) 
Table 6. Allochthonous energy base in temperate and tropical streams.

\begin{tabular}{|c|c|c|c|c|c|}
\hline Zone & Country & Stream Order & Stream Width $(\mathrm{m})$ & $\begin{array}{c}\text { Allochthonous Energy } \\
\text { Base }(\%)\end{array}$ & References \\
\hline \multirow[t]{5}{*}{ Temperate } & United States & $1-2$ & $<2.7$ & 85 & Wallace et al. (1997), Hall et al. (2001) \\
\hline & United States & & $1.2-4.7$ & 80 & England and Rosemond (2004) \\
\hline & United States & Small Streams & & 90 & Minshall (1967) \\
\hline & New Zealand & $1-2$ & $0.6-2.6$ & Primarily allochthonous & Hicks (1997) \\
\hline & New Zealand & & $1.0-2.8$ & Primarily allochthonous & Rounick et al. (1982) \\
\hline \multirow[t]{6}{*}{ Tropical } & Puerto Rico & $2-4$ & $13.0-19.0$ & $<50$ & March and Pringle (2003) \\
\hline & Brazil & & $10.0-18.0$ & $<40$ & Brito et al. (2006) \\
\hline & Hong Kong & 3 & $8.0-12.0$ & $<40$ & Mantel et al. (2004) \\
\hline & & & & & Li and Dudgeon (2008) \\
\hline & & & & & Dudgeon et al. (2010) \\
\hline & Mexico & 1 & $1.6-2.5$ & $40-80$ & This study \\
\hline
\end{tabular}

perhaps it is due to the relatively nutritious value of fungi (Cummins \& Klug, 1979), which are not limited by reduced sunlight and can colonize allochthonous material (Graça, 2006).

The presence of recognizable animal tissue in the diets of the predatory taxa Diplectrona and Lepidostoma has also been reported in other studies (Hall et al., 2001; Merritt et al., 2008; Tomanova et al., 2006). These two taxa have larger body sizes that allow for access to larger portions of prey with high nutritional value (Cummins \& Klug, 1979); smaller aquatic insects that consume this resource would ingest small pieces that may end up being classified as amorphous detritus (Palmer et al., 1993).

Trophic base for aquatic insects. Two methods have been commonly used to characterize the energy base sustaining aquatic insect assemblages: gut content analysis and analysis of the stable isotopes of carbon $\left({ }^{13} \mathrm{C}\right)$ and nitrogen $\left({ }^{15} \mathrm{~N}\right)$ (Winterbourn et al., 1984; Hall et al., 2001; England \& Rosemond, 2004; Lau et al., 2009a; 2009b; Dudgeon et al., 2010). The use of stable isotopes provides information on the percentage of ${ }^{13} \mathrm{C}$ and ${ }^{15} \mathrm{~N}$ assimilated by organisms using different food resources, provided that the isotopic signature of these elements can be differentiated between different food sources (Winterbourn et al., 1984; Hicks, 1997; Dudgeon et al., 2010). Although gut content analysis can identify energy sources for aquatic insects, and allow for inferences of their consumption habits (Cummins, 1973; Mantel et al., 2004; Lau et al., 2009a; Dudgeon et al., 2010), it is not always possible to classify all gut contents. However, it is noteworthy that in several studies the two approaches show similar trends in the determination of the contribution of the energy sources used for food webs (Winterbourn et al., 1984; Hicks, 1997; Mantel et al., 2004; McNeely et al., 2007; Lau et al., 2009a).

The forest stream is definitely a heterotrophic system, as reported for temperate headwater streams (Hynes, 1975; Vannote et al., 1980). Only four of the thirteen taxa examined had less than $50 \%$ allochthonous material in their gut contents, and this occurred during the dry season when the availability of autochthonous material was high. The higher nutritional importance of autochthonous material (algae) helps to explain why the trophic base in the forest stream is partly autochthonous, especially during the dry season (Cummins \& Klug, 1979).

The proportion of allochthonous material used as an energy base was intermediate, relative to those reported from temperate and tropical lowland streams (Table 6) (Rounik et al., 1982; Winterbourn et al., 1984; Hall et al., 2001; Rosi-Marshall \& Wallace, 2002; March \& Pringle, 2003; Lau et al., 2009b; Dudgeon et al., 2010). This is likely because in this study we excluded the proportion of amorphous detritus when estimating the trophic base (allochthonous - autochthonous). If data were collected on the proportion of allochthonous and autochthonous organic matter for fine suspended particles in the water column (e.g., Mantel et al., 2004; Dudgeon et al., 2010), it might have been possible to quantify the proportional contribution of allochthonous and autochthonous material to the energy base for amorphous detritus. Thus, we would expect the proportion of allochthonous energy to be greater, because a large quantity of this ingested detritus corresponds to fine particulate organic matter, which is potentially composed primarily of allochthonous material in the forest stream, given the low availability of autochthonous material, contrary to what occurs in the pasture stream.

The largest proportion of allochthonous material used as an energy base was found in the forest stream, contrasting with findings from other tropical streams, even with conserved riparian vegetation (March \& Pringle, 2003; Mantel et al., 2004; Brito et al., 2006; Dudgeon et al., 2010). One possible explanation is that in our study streams are narrower than those used in previous studies. In those studies, riparian vegetation leaves a more open canopy and the production of autochthonous material is not limited by incident solar radiation (Vannote et al., 1980). In our study, we sampled first order streams that were less than $3 \mathrm{~m}$ wide, while previous studies focused on streams ranging from second to fifth order, with widths greater than $8 \mathrm{~m}$ (Table 6) (March \& Pringle, 2003; Mantel et al., 2004; Brito et al., 2006; Dudgeon et al., 2010).

According to expectations, in the pasture stream, which lacked riparian vegetation, most taxa examined depended on an autochtho- 

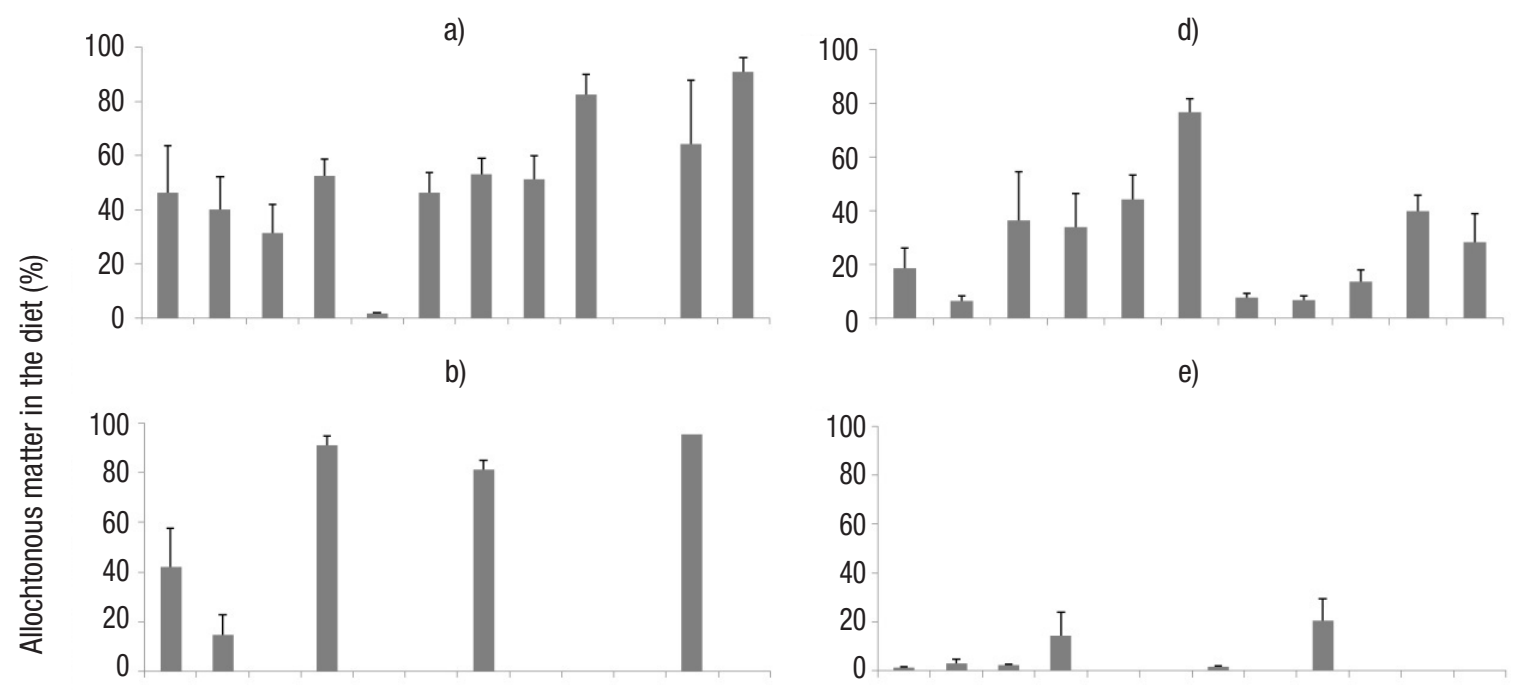

e)
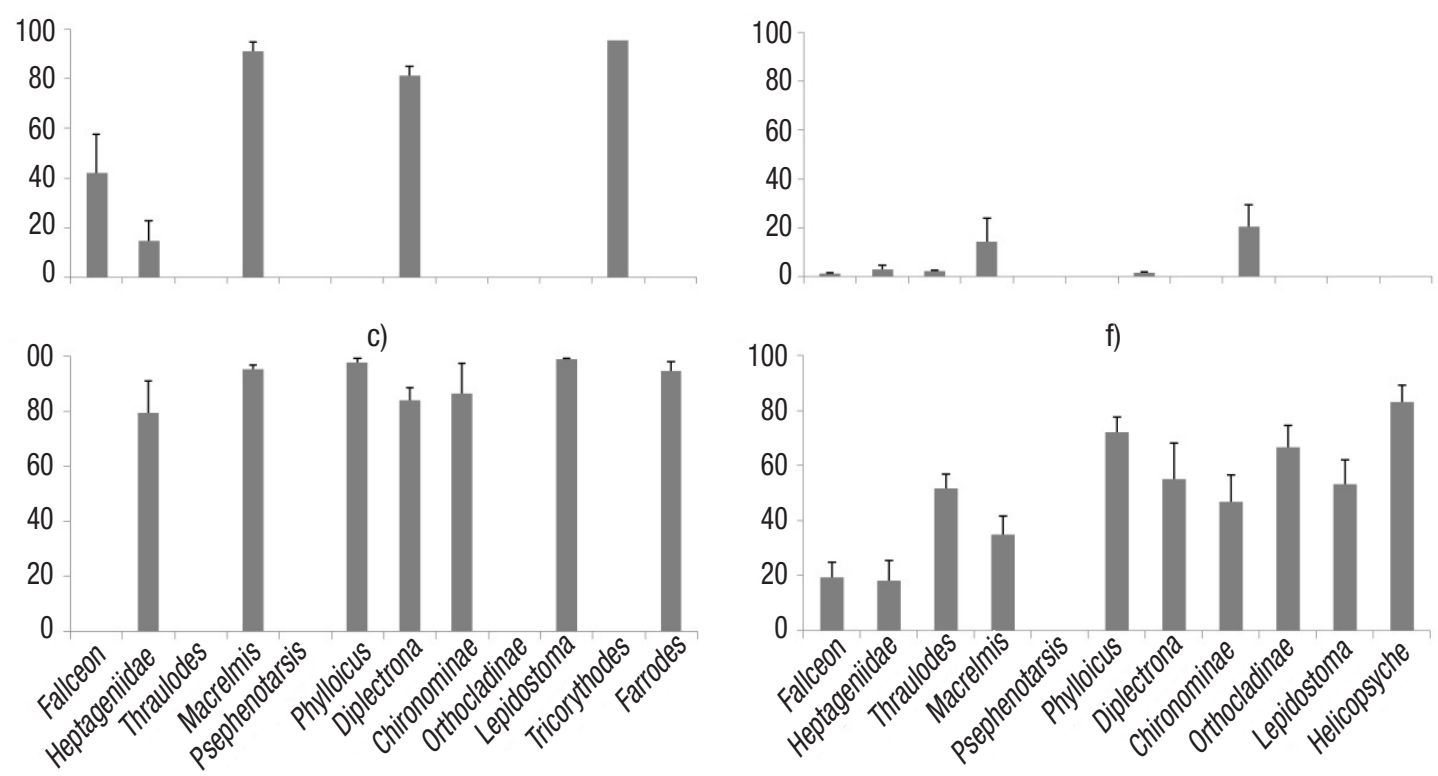

Figures 6a-f. Average proportion and standard error of allochthonous material in the diet of aquatic insects from two streams in La Cortadura, Coatepec, Veracruz, Mexico. a) Taxa examined from the forest stream during dry season; b) From rainy season; c) From the "Nortes" season; d) Taxa examined from the pasture stream during dry season; e) From rainy season; f) From the "Nortes" season.

nous energy base, contrasting with the forest stream (Minshall, 1978; Vannote et al., 1980). Although allochthonous material was available in the pasture stream, Phylloicus was the only insect heavily relying on it during all seasons, while other taxa used allochthonous material during the "nortes" season when the availability of autochthonous material was lower. The increased proportion of taxa relying on autochthonous material during the rainy season in the pasture stream likely arose due to the increased availability of benthic algae per individual (McNeely et al., 2007). Thus, the proportion of allochthonous and autochthonous material in the gut contents of aquatic insects reflected variations in the availability of these resources in the environment.

Deforestation not only affects the availability of allochthonous and autochthonous materials in streams (Rosi-Marshall \& Wallace, 2002), it can also modify species assemblages, altering diversity and functionality (Benstead \& Pringle, 2004). In this study, we found that some taxa (e.g., Fallceon, Chironominae, and Heptageniidae) had sufficient flexibility to change their energy base because of increased availability of autochthonous material in the pasture stream that suffered loss of riparian vegetation. In contrast, other taxa such (e.g., Phylloicus) maintained a high proportion of an allochthonous energy base. We can expect that further increases in the loss of watershed vegetation will reduced the availability of allochthonous material, and thus the stream insect assemblage will lose those taxa that are unable to change their diets from an allochthonous energy base.

Aquatic insects in montane cloud forest streams are mostly food generalists. Autochthonous material was an important part of the trophic base for these organisms in the two stream types studied, even when its availability might have been limited by shade from riparian vegetation in the forest stream. There was dietary flexibility for the insects examined and therefore variation in the trophic base in response to variations in the combined availability of autochthonous and allochthonous resources. The removal of riparian vegetation increased the availability of autochthonous material, thus increasing its use by aquatic insects.

\section{ACKNOWLEDGEMENTS}

We are grateful to José Antonio Gómez for support he gave during our field work; to Arlet Fuentes and Ariadna Martínez who supported us in the lab; to Rosa Alicia Jiménez, Sergio Ibáñez, and Federico Escobar for their comments on our work and manuscript. The work described in this paper was supported by a scholarship (250337) for the first author and a grant for the project No. 101542 from National Council for Science and Tecnology (CONACyT). 


\section{REFERENCES}

Allan, J. \& M. Castillo. 2007. Stream ecology. Structure and function of running waters. 2nd ed. Springer, Dondrecht, The Netherlands. 433 p. DOI: $10.1007 / 978-1-4020-5583-6$

AndeRson, M. 2001. A new method for non-parametric multivariate analysis of variance. Austral Ecology 26: 32-46. D0I: 10.1111/ j.1442-9993.2001.01070.pp.x.

Anderson, M. 2006. Distance-based tests for homogeneity of multivariate dispersions. Biometrics 62: 245-253. D0I: 10.1111/j.15410420.2005.00440.x

Anderson, M., R. Gorley \& K. Clarke. 2008. PeRManOVA+ for PRIMER. Guide to software and statistical methods. PRIMER-E: Plymouth, UK.

Ardón, M. \& C. M. Pringle. 2008. Do secondary compounds inhibit microbial- and insect-mediated leaf breakdown in a tropical rainforest stream, Costa Rica? Oecologia 155: 311-323. D0I: 10.1007/ s00442-007-0913-x

BenfieLd, E. 2007. Decomposition of leaf material. In: Hauer, R. \& G. Lamberti (Eds.). Methods in stream ecology, Second edition. Elsevier Inc., San Diego, CA: 51-78.

Benstead, J. P. \& C. M. Pringle, 2004. Deforestation alters the resource base and biomass of endemic stream insects in eastern Madagascar. Freshwater Biology 49: 490-501. DOI: 10.1111/j.13652427.2004.01203.x

Benstead, J. P., M. Douglas \& C. M. Pringle. 2003. Relationships of stream invertebrate communities to deforestation in eastern Madagascar. Ecological Applications 13: 1473-1490. D0I: 10.1890/02-5125

BIGgs B. 1996. Patterns in benthic algae of streams. In: Stevenson, R. J., M. L. Bothwell \& R. L. Lowe (Editores), Algal Ecology: Freshwater Benthic Ecosystems. Academic Press, San Diego (CA): 31-56.

Bourelly P. 1966. Les algues d'eau douce. Initiation á la systématique. Tome I: Les algues vertes. IV. Boubée \& Cie, Paris, France.

Boyero, L., A. Ramírez, D. Dudgeon\& R. Pearson. 2009. Are the tropical streams really different? Journal of the North American Benthological Society 28: 397-403. DOI: 10.1899/08-146.1

Brito, E., T. Moulton, M. De Souza \& S. Bunn. 2006. Stable isotope analysis indicates microalgae as the predominant food source of fauna in a coastal forest stream, south-east Brazil. Austral Ecology 31: 623633. D0I: $10.1111 / \mathrm{j} .1442-9993.2006 .01610 . x$

Cummins, K. 1973. Trophic relations of aquatic insects. Annual Review of Entomology 18: 183-206. D0l: 10.1146/annurev.en.18.010173.001151

Cummins, K. \& M. KLug. 1979. Feeding ecology of stream invertebrates. Annual Review of Ecology and Systematics 10: 147-172. DOI: 10.1146/annurev.es.10.110179.001051

Cummins K., R. Merritt \& P. Andrade. 2005. The use of invertebrate functional groups to characterize ecosystem attributes in selected streams and rivers in south Brazil. Studies on Neotropical Fauna and Environment 40: 69-89. D0I: 10.1080/01650520400025720
Dudgeon, D., F. Cheung \& S. Mantel. 2010. Foodweb structure in small streams: do we need different models for the tropics? Journal of the North American Benthological Society 29: 395-412. DOI: $10.1899 / 09-058.1$

ENGLAND, L. \&A. D. ROSEMOND. 2004. Small reductions in forest cover weaken terrestrial aquatic linkages in headwater streams. Freshwater Biology 49: 721-734. DOI: 10.1111/j.1365-2427.2004.01219.x

FisheR, S. \& G. LIKENS. 1973. Flow in Bear Brook, New Hampshire: an integrative approach to stream ecosystem metabolism. Ecological Monographs 43: 421-439. D0I: 10.2307/1942301

Garcia-Franco, J., G. Castillo-Campos, K. Mehltreter, M. Martínez \& G. VázQUEZ. 2008. Composición florística de un bosque mesófilo del centro de Veracruz, México. Boletín de la Sociedad Botánica de México 83: 37-52.

Gore, J. 2007. Discharge measurements and streamflow analysis. In: Hauer, R. \& G. Lamberti (Eds.). Methods in stream ecology. 2nd ed.. Elsevier Inc., San Diego, CA: 51-78.

GraçA, M., 2006. Allochthonous organic matter as a food resource for aquatic invertebrates in forested streams. In: Codero-Rivera, A. (Ed.). Forests and dragonflies. Pensoft, Sofia-Moscow: pp. 37-47.

GrIMM, N. \& S. FiSHER. 1989. Stability of periphyton and macroinvertebrates to disturbance by flash floods in a desert stream. Journal of the North American Benthological Society 8: 293-307. DOI: $10.2307 / 1467493$

Hall, R., G. Likens\& H. Malcom. 2001. Trophic basis of invertebrate production in 2 streams at the Hubbard Brook experimental forest. Journal of the North American Benthological Society 20: 432-447. DOI: $10.2307 / 1468040$

HIcks, B. 1997. Food webs in forest and pasture streams in the Waikato region, New Zealand: a study on analyses of stable isotopes of carbon and nitrogen, and fish gut contents. New Zealand Journal of Marine and Freshwater Research 31: 651-666. D0I: 10.1080/00288330.1997.9516796

HILL, W., 1996. Effects of light. In: Stevenson, R. J., M. L. Bothwell \& R. L. Lowe (Eds.). Algal ecology: freshwater benthic ecosystems. Academic Press, San Diego, CA: 121-148.

Hynes, H. 1975. The stream and its valley. Verhandlugen der Internationalen Verrinigung für Theoretische und Angewandte Limnologie 19: 1-15.

Jacobsen, D., C. Cressa, J. M. Mathooko \& D. Dudgeon. 2008. Macroinvertebrates: composition, life histories and production. In: Dudgeon, D. (Ed.). Tropical stream ecology. Academic Press, London: 66-106.

Kramer, K. \& H. Lange-Bertalot. 1991a. Bacillariophyceae. 3 Teil: Centrales, Fragilariaceae, Eunotiaceae. 166 tafeln mit 2180 figuren. Gustav Fischer Verlag, Stuttgart, Germany.

Kramer, K. \& H. Lange-Bertalot. 1991b. Bacillariophyceae. 4. Teil:Achnanthaceae, Kriticsche Erganzungen zu Navicula Lineolatae und Gomphonema Gesamliter-atuverzeichnis Teil 1-4-88 tafeln mit 2048 figuren. Gustav Fischer Verlag Stuttgart, Germany. 
Kramer, K. \& H. Lange-Bertalot. 1997. Bacillariophyceae. 2. Teil: Bacillariaceae, Epithemiaceae, Surirellaceae. 184 Tafeln mit 1914 Figuren. Spektrum Akademischer Verlag, Germany.

Kramer, K. \& H. Lange-Bertalot. 1999. Bacillariophyceae. 1. Teil: Naviculaceae. 206 tafeln mit 2976 figuren. Spektrum Akademischer Verlag, Germany.

Larned, S. T. \& S. Santos. 2000. Light and nutrient limited periphyton in low order streams of Oahu, Hawaii. Hydrobiologia 432: 101-111. DOI: $10.1023 / \mathrm{A}: 1004074004416$

Lau, D., K. Leung \& D. Dudgeon. 2009a. Are autochthonous foods more important than allochthonous resources to benthic consumers in tropical headwater streams? Journal of the North American Benthological Society 28: 426-439. DOI:10.1899/07-079.1

Lau, D., K. Leung\& D. Dudgeon. 2009b. What does stable isotope analysis reveal about trophic relationships and the relative importance of allochthonous and autochthonous resources in tropical streams? A synthetic study from Hong Kong. Freshwater Biology 54: 127-141. DOI: 10.1111/j.1365-2427.2008.02099.x

Legendre, P. \& L. Legendre. 1998. Numerical ecology. 2nd Ed. Elsevier Science B.V., The Netherlands. $853 \mathrm{p}$.

LeUng, A. \& D. Dudgeon. 2011. Scales of spatiotemporal variability in macroinvertebrate abundance and diversity in monsoonal streams: detecting environmental change. Freshwater Biology 56: 11931208. DOI: 10.1111/j.1365-2427.2010.02556.x

LI, A. \& D. Dudgeon. 2008. Food resources of shredders and other benthic macroinvertebrates in relation to shading conditions in tropical Hong Kong streams. Freshwater Biology 53: 2011-2025. DOI: 10.1111/j.1365-2427.2008.02022.x

Mantel, S., M. Salas \& D. Dudgeon. 2004. Food web structure in a tropical Asian forest stream. Journal of the North American Benthological Society 23: 728-755. DOI: 10.1899/0887-3593(2004)023<0728: FSIATA $>2.0 . C 0 ; 2$

MARCh, J. G. \& C. M. Pringle. 2003. Food web structure and basal resource utilization along a tropical island stream continuum, Puerto Rico. Biotropica 35: 84-93. DOI: 10.1111/j.1744-7429.2003.tb00265.x

McNeely, C., J. Finlay \& M. Power. 2007. Grazer traits, competition, and carbon sources to a headwater-stream food web. Ecology 88: 191401. D0I: 10.1890/0012-9658(2007)88[391:GTCACS]2.0.C0;2

MeEks, C. 1974. Chlorophylls. In: Stewart, P. (Ed.). Algal physiology and biochemistry. Blackwell Scientific Publications Ltd., Great Britain. pp. 161-174.

MerRitt, R., K. Cummins \& M. Berg. 2008. An introduction to the aquatic insects of North America. 4th Ed. Kendall-Hunt Publishing, lowa, USA.

MinshalL, G. 1978. Autotrophy in stream ecosystems. BioScience 28: 767-771. DOI: $10.2307 / 1307250$

Molina, C., F. Gibon, T. Oberdorff, E. Dominguez, J. Pinto, R. Marin\& M. Roulet. 2011. Macroinvertebrate food web structure in a floodplain lake of the Bolivian Amazon. Hydrobiologia 663: 135-153. D0I: 10.1007/ s10750-010-0565-4
Muñoz-VIlLeRs, L. 2008. Efecto del cambio del uso de la tierra sobre la dinámica hidrológica y calidad del agua en el trópico húmedo del centro de Veracruz, México. Doctoral Dissertation. Universidad Autónoma Metropolitana, México. 278 p.

Palmer, C., J. O'Keeffe, A. Palmer, T. Dunne \& S. Radloff. 1993. Macroinvertebrate functional feeding groups in the middle and lower reaches of the Buffalo River, eastern Cape, South Africa. I. Dietary variability. Freshwater Biology 29: 441-453. D0I: 10.1111/j.1365-2427.1993. tb00778.x

Ramirez, A. \& C. M. Pringle. 1998. Structure and production of a benthic insect assemblage in a neotropical stream. Journal of the North American Benthological Society 17: 443-463. D0I: 10.2307/1468365

Rosi-Marshall, E. \& J. B. Wallace. 2002. Invertebrate food webs along a stream resource gradient. Freshwater Biology 47: 129-141. DOI: 10.1046/j.1365-2427.2002.00786.x

Rounik, J., M. WinterbouRn \& G. Lyon. 1982. Differential utilization of allochthonous and autochthonous inputs by aquatic invertebrates in some New Zealand streams: a stable carbon isotope study. Oikos 39: 191-198. DOI: $10.2307 / 3544485$

RzEDowski, J. 1978. Vegetación de México. Editorial Limusa. México, D. F. $432 \mathrm{p}$.

RzEDowskı, J. 1996. Análisis preliminar de la flora vascular de los bosques mesófilos de montaña de México. Acta Botánica Mexicana 35: 25-44.

Tomanova, S., E. Goitia \& J. Helešlc. 2006. Trophic levels and functional feeding groups of macroinvertebrates in neotropical streams. Hydrobiologia 556: 251-264. DOI: 10.1007/s10750-005-1255-5

Vannote, R., G. Minshall, K. Cummins, J. Sedell \& C. Cushing. 1980. The river continuum concept. Canadian Journal of Fisheries and Aquatic Sciences 37: 130-137. DOI: 10.1139/f80-017

Vázquez, G., J. Aké-CAstlllo \& M. Favila. 2011. Algal assemblages and their relationship with water quality in tropical Mexican streams with different land uses. Hydrobiologia 667: 173-189. D0I: 10.1007/ s10750-011-0633-4

Wallace, J. B., S. Eggert, J. Meyer \& J. Webster. 1997. Multiple trophic levels of a forest stream linked to terrestrial litter inputs. Science 277: 102-104. D0I: 10.1126/science.277.5322.102

Webster, J. R., E. F. Benfield, T. P. Ehrman, M. A. Schaeffer, J. L. Tank, J. J. Hutchens \& D. J. D'Angelo. 1999. What happens to allochthonous material that falls into streams? A synthesis of new and published information from Coweeta. Freshwater Biology 41: 687-705. D0l: 10.1046/j.1365-2427.1999.00409.x

Willams-Linera, G. 2007. El bosque de niebla del centro de Veracruz: ecología, historia y destino en tiempos de fragmentación y cambio climático. CONABIO-Instituto de Ecología A.C., Xalapa, Veracruz, México.

Winterbourn, M., J. CoWie \& J. Rounick. 1984. Food resources and ingestion patterns of insects along a West Coast South Island river system. New Zealand Journal of Marine and Freshwater Research 18: 43-51. DOI: 10.1080/00288330.1984.9516058 